\title{
ANT ASSEMBLAGES (HYMENOPTERA: FORMICIDAE) ASSOCIATED TO ENVIRONMENTS OF A RURAL PROPERTY IN THE EXTREME WESTERN REGION OF THE STATE OF SANTA CATARINA \\ ASSEMBLEIAS DE FORMIGAS (HYMENOPTERA: FORMICIDAE) ASSOCIADAS A AMBIENTES DE UMA PROPRIEDADE RURAL DO EXTREMO OESTE CATARINENSE
}

\section{Junir Antonio Lutinski}

PhD. in Animal Biodiversity at the Universidade Federal de Santa Maria (UFSM). Professor of the Graduate Program in Health Science, Universidade Comunitária Regional de Chapecó (Unochapecó) Chapecó (SC), Brazil.

\section{Cladis Juliana Lutinski}

MSc. in Environmental Science, Unochapecó. Biologist of Biology Laboratory, Universidade Federal da Fronteira Sul (UFFS) Chapecó (SC), Brasil.

\section{Juliane Freitag Beling}

Nursing Student, Unochapecó Chapecó (SC), Brazil.

\section{Maria Assunta Busato}

PhD. in Biology, Universitat de Barcelona. Professor of the Graduate Program in Health Science, Unochapecó-Chapecó (SC), Brazil.

\section{Vanessa Corralo}

PhD. in Biology, UFSM. Professor of the Graduate Program in Health Science, Unochapecó Chapecó (SC), Brazil.

\section{Corresponding address:}

Junir Antonio Lutinski - Rua BeijaFlor, 254 E - Efapi - CEP 89809-760 Chapecó (SC), Brasil -

E-mail: junir@unochapeco.edu.br

Received on: 08/02/2016

Accepted on: $11 / 30 / 2017$

\section{ABSTRACT}

The conversion of natural environments into agricultural areas has led to habitat fragmentation and caused impacts on biological communities. This study evaluated the richness and abundance of ant assemblages from different environments within a small rural property. The study was conducted in December 2015 in the Palma Sola municipality, extreme western region of the state of Santa Catarina, Brazil. The sampled environments included a permanent preservation area, a forest fragment, a corn crop, a tobacco crop and a pine reforestation. Pitfall traps and manual collections were used. The observed richness totaled 69 species. Only two species, Camponotus rufipes and Pheidole lignicola, occurred in the five environments sampled. Overall, $65.3 \%$ of the variation in ants' occurrence, according to the sampled environments, was explained by the principal component analysis (PCA) components. This study presents new results on the ant diversity from rural areas, and may provide potential subsidies for management and conservation plans.

Keywords: agro ecosystems; agrochemicals; ant fauna; conservation; richness.

\section{RESUMO}

A transformação de ambientes naturais em áreas agrícolas vem provocando a fragmentação ambiental e gerando impactos sobre as comunidades de organismos. Este estudo avaliou a riqueza e a abundância das assembleias de formigas de ambientes que compõem uma propriedade rural. $O$ estudo foi conduzido no município de Palma Sola, extremo oeste catarinense, no mês de dezembro de 2015. Os ambientes avaliados foram uma área de preservação permanente, um fragmento florestal, uma lavoura de milho, uma lavoura de tabaco e um reflorestamento de pinus. Foram utilizadas armadilhas de queda e coleta manual. A riqueza amostrada foi de 69 espécies. Apenas duas espécies, Camponotus rufipes e Pheidole lignicola, ocorreram nos cinco ambientes amostrados. Ao todo, $65,3 \%$ da variação das ocorrências de formigas segundo os ambientes amostrados foi explicada pelos componentes da análise de componentes principais (ACP). Este estudo apresenta indicativos da diversidade presente em ambientes rurais e pode representar subsídios para planos de manejo e conservação.

Palavras-chave: agroecossistemas; agrotóxicos; mirmecofauna; conservação; riqueza. 


\section{INTRODUCTION}

The conversion of natural environments into agricultural areas (TANENTZAP et al., 2015) has led to a growing concern about the impacts on biological communities caused by monocultures, habitat fragmentation and pesticide use (GALINDO-LEAL; CÂMARA, 2003; EDWARDS et al., 2014). However, little is known about the impacts of conventional agricultural crops on the richness and abundance of organisms inhabiting directly affected areas. Likewise, it remains poorly known the role of small forest fragments, permanent preservation areas (APP) and reforestations as potential reservoirs (DECOCQ et al., 2016), contributing for the maintenance of insect diversity in the mosaic of environments that typically compose small rural properties.

The western region of the Brazilian state of Santa Catarina is characterized, with regard to its economy, by the family farming with the predominance of small properties (up to 25 hectares), whose livelihood is based on grain planting (corn, soy, beans, and wheat), milk production, pig farming, poultry and tobacco production (IBGE, 2015). The land used on these farms is often characterized by a fragmented environment destined to distinct activities. It includes environments destined to agricultural crops, pastures, permanent preservation, conservation, and reforestation (LUTINSKI et al., 2017). The biological communities in such environments suffer varying impacts related to agricultural activities, ranging from minimal impacts in preserved fragments to more severe impacts in the cultivated areas, as for instance the frequent use of pesticides (herbicides, insecticides, nematicides and fungicides) (CHAGNON et al., 2015).

The study of ant assemblages in small farms contributes for understanding the key factors for the ant diversity conservation, as well as to the sustainability of the different farm environments, given that Formicidae is one of the most diverse insect taxa (HÖLLDOBLER; WILSON, 1990; LUTINSKI et al., 2017; HOLDEFER et al., 2017), characterized by its wide distribution and high richness and abundance in terrestrial environments (PÉREZ-SÁNCHEZ et al., 2013; WIELGOSS et al., 2013). The number of studies on the occurrence of ants in agricultural ecosystems is growing, and though these studies discuss ecological aspects of some species of major importan- ce (CHEVALIER et al., 2013; PÉREZ-SÁNCHEZ et al., 2013; HOLDEFER et al., 2017), they do not clearly emphasize the diversity of assemblages or aspects that could interfere on the ants conservation.

Ants have been regarded as bioindicator organisms due to their wide distribution, rapid response to environmental changes and biological relevance in different trophic levels (CREPALDI et al., 2014; BHARTl et al., 2016; LUTINSKI et al., 2017). In agro ecosystems, ants act in seed dispersal, soil enrichment and aeration, although species like Atta spp. and Acromyrmex spp. may damage crops (LUTINSKI et al., 2008; 2017; NICKELE et al., 2016).

The ants present high richness of species and are ecologically important in the different strata of terrestrial ecosystems (BACCARO et al., 2015). The richness and diversity of ants tend to increase according to the complexity of the environments, due to the greater availability of present niches (ROCHA et al., 2015; HOLDEFER et al., 2017). In order to evaluate the environmental impact of these insects, it has been proposed that these insects should be used as a tool for the environmental monitoring of areas under anthropogenic disturbance conditions.

The ants present characteristics such as the easy sampling, high abundance, broad geographic distribution, importance in the functioning of the ecosystems, and well-known ecology and taxonomy (AGOSTI et al., 2000; ROCHA et al., 2015). Ants have been used in the evaluation of pesticide contamination, in habitat disturbances, in the evaluation of the impact of deforestation (ILHA et al., 2009), in the urbanization process impact (LUTINSKI et al., 2013a), in the monitoring of mining areas (ROCHA et al., 2015) and energy production (LUTINSKI et al., 2017). Studies focusing on the diagnosis and conservation of the ant fauna on rural properties in the south of Brazil are rare (HOLDEFER et al., 2017). In this context, researches are needed to identify resilient species capable of colonizing such environments and exploring the importance of permanent preservation and environmental protection areas for biodiversity conservation in small rural properties.

The knowledge about the richness and abundance of ant assemblages in a given ecosystem can support con- 
servation plans (ILHA et al., 2009; LAWES et al., 2017). Information on the ant fauna from small farm environments contributes to understand the impact of conventional farming monocultures on these insects, and to comprehend the role of protected environments as biodiversity reservoirs.

In this context, the aims of this study were:
- To characterize the ant assemblages in five environments from a rural property located in the extreme western region of Santa Catarina;

- To compare the five environments regarding the richness of their ant assemblages;

- To evaluate the relationship between the abundance of ant assemblages and the five environments sampled within the rural property.

\section{MATERIAL AND METHODS}

\section{Characteristics of the sampled environments}

The study was conducted in a rural property located in the municipality of Palma Sola (26037'19"S, $\left.53 \circ 40^{\prime} 01^{\prime \prime} \mathrm{W}\right)$, extreme western region of the state of Santa Catarina, Brazil. The study site is an area of approximately 19 ha composed by small fragments of Atlantic forest (mixed ombrophilous forest), a permanent preservation area (PPA) alongside the river Tracutinga, pasture areas, a pine reforestation fragment (Pinus elliottii Engelm.), an area occupied by the property buildings, and the remaining area occupied by crops of corn (Zea mays L.), bean (Phaseolus vulgaris L.) and tobacco (Nicotiana tabacum L.). The local climatic type is characterized as "mesothermal superhumid subtropical humid", without a dry season and with regular frosts and rainfall evenly distributed along the year (RAMOS et al., 2009).

We sampled five environments with approximately one ha each, as it follows:

- A PPA with a 30-year conservation history, formed by riparian native forest with sparse undergrowth vegetation;

\section{Ant collection}

We did a sampling in December 2015 using pitfall traps and manual collections in all environments. The pitfall traps consisted of plastic cups with $500 \mathrm{~mL}$ capacity (10 $\mathrm{cm}$ in diameter by $12 \mathrm{~cm}$ in height) buried at the ground level (LUTINSKI et al., 2013b). In each trap, we added $150 \mathrm{~mL}$ of water and two detergent drops in order to break the water surface tension, causing the insects to sink immediately after falling into the trap. In each environment we installed 10 pitfalls along a linear transect perpendicular to the edge, observing
- A forest fragment (FF) with no history of deforestation and with a dense undergrowth vegetation;

- A pine reforestation (PR) aged 20 years, with sparse undergrowth vegetation formed by shrubs and local native plants;

- A corn crop (CC), conventionally cultivated in pre-harvest stage, where the following pesticides were used: acaricide belonging to the group of organophosphates (O, S-dimethyl-acetylphosphoramidothioate) (acephate); neonicotinoid insecticide (1-(6-chloro-3-pyridylmethyl) -N-nitroimidazolidin-2-ylideneamine (imidacloprid) and the aminophosphorade herbicide $\mathrm{N}$-(phosphonomethyl)-glycine) (glyphosate), with one application during cultivation;

- A tobacco crop (TC), conventionally cultivated in pre-harvest stage, where the following pesticides were used: acephate, imidacloprid and glyphosate, with one application during cultivation.

the distance of 10 meters between consecutive traps (LUTINSKI et al., 2013b). The traps were kept open during a period of 48 hours.

Manual sampling was conducted following a random transect for one hour in each environment, using a gripper and a cotton swab moistened in alcohol for catching the specimens. In the FF, PPA and PR, samplings were carried out on the soil, shrubs and tree trunks up to a maximum height of two meters; in the TC and CC, samplings were performed directly on the soil. 


\section{Identification of the collected material}

The collected material was placed in vials containing $70 \%$ alcohol, labeled and transported to the Entomology Laboratory of the Universidade Comunitária da Região de Chapecó (Unochapecó) for

\section{Statistical analysis}

Richness was defined as the number of species that occurred in each sample. Abundance was defined based on the relative frequency (i.e., the number of records of a given species in each trap) - and not based on the number of individuals - , which is more suited for studies of ant assemblages because it minimizes the effects of foraging habit and colony size (LUTINSKI et al., 2017). The relative frequency of each species in each environment was calculated by the following equation: $\mathrm{F}=\mathrm{Fi} \times 100 / \mathrm{Ft}$, in which $\mathrm{Fi}$ is the number of occurrences of a given species in a given environment, and $\mathrm{Ft}$ is the total number of occurrences of that species in a given environment.

In order to verify the sampling sufficiency, we did a comparison between the species observed in the samples (Sobs) and the value generated by the Chao 2 es- further sorting and taxonomic identification. Once in the laboratory, the specimens were identified using the taxonomic keys proposed by Fernández (2003) e Wild (2007).

timator. This comparison allows inferring how much a survey approximates to an all-species sampling in a given environment. The richness estimates for each environment were obtained using the software EstimateS 8.2. The richness of ants sampled in each environment was compared by a rarefaction analysis based on species occurrences. This analysis was performed in the software EcoSim 7 (GOTELLI; ENTSMINGER, 2001).

The relationship between ant species and the different environments was verified through the principal component analysis (PCA). Forty-four ant species were excluded from this analysis due to their small number of occurrences in the samples $(\leq 2)$. The data were previously transformed into Log $(x+1)$ and then analyzed using the software Past (HAMMER et al., 2001).

\section{RESULTS}

We identified 69 species belonging to 22 genera, 15 tribes and eight subfamilies (Table 1). The ant assemblage from the forest fragment had the highest richness of species $(S=37)$, followed by the PPA $(S=35), P R(S=25)$, CC $(S=13)$ and TC $(S=9)$ assemblages. Only two species, Camponotus (Myrmothrix) rufipes (Fabricius, 1775) and Pheidole (Pheidole) lignicola (Mayr, 1887), occurred in all five sampled environments. Overall, $38(55 \%)$ species occurred in only one environment. The assemblage of the FF had Gnamptogenys striatula (Mayr, 1884), Pachycondyla striata (F. Smith, 1858) and Heteroponera inermis (Emery, 1894) as the most frequent species. In the PPA, the most frequent species were $G$. striatula, Pheidole (Pheidole) risii (Forel, 1892) and Pogonomyrmex angustus (Mayr, 1870); in the PR, the most frequent species were $P$. striata, $P$. lignicola and Pheidole sp. 2; in CC, Dorymyrmex brunneus (Forel, 1908) and C. rufipes; and in TC, Solenopsis sp. 1 and P. lignicola (Table 1).

The major difference (100\%) between the observed (Sobs) and the estimated richness (Chao 2) was found for the ant assemblages of the CC (Chao $2=26)$ and TC
(Chao 2 = 18). In the FF, in turn, this difference was $76 \%$ (Chao $2=65$ ), whereas in the PR it was of $72 \%$ (Chao $2=43$ ), and in the PPA it decreases to $52 \%$ (Chao 2 $=54$ ). The trend for increasing the species richness if additional samples were made is evident by the rarefaction curves, because none of the environments reached an asymptote. The FF and the PPA presented the highest richness, whilst the lowest richness occurred in the TC environment (Figure 1).

Altogether, $65.30 \%$ of the variation in the occurrence of ants, according to the sampled environments, was explained by the first (eigenvalue: $0.17 ; \%$ of variance: 39.00 ) and second (eigenvalue: $0.12 ; \%$ of variance: 26.30) PCA components. Three species showed a positive association with the samplings made in the FF and PPA: G. striatula, P. risii and P. striata; two species with the sampling made in the PR: P. lignicola and Pheidole sp. 2; and four species with the sampling carried out in the CC and TC: $C$. rufipes, $D$. brunneus, Pheidole sp. 4 and Solenopsis sp. 1 . All other ant species occurred regardless of the environment type (Figure 2). 
Table 1 - Richness and frequency of ant assemblages sampled in five environments of a rural property in the municipality of Palma Sola, western Santa Catarina, Brazil (December 2015).

Taxon Of a rural property in the municipality of Palma Sola, western Santa $\mathrm{FF}$ CC TC

Subfamily Dolichoderinae

Tribe Dolichoderina

Dorymyrmex brunneus (Forel, 1908)

Linepithema gallardoi (Kusnezov, 1969)

Linepithema humile (Mayr, 1868)

Linepithema iniquum (Mayr, 1870)

PPA

FF

\begin{tabular}{|l|l|}
\hline & 0.01 \\
\hline 0.04 & 0.03 \\
\hline 0.07 & \\
\hline 0.01 & \\
\hline
\end{tabular}

Linepithema micans (Forel, 1908)

Linepithema sp.

Subfamily Ecitoninae

Tribe Ecitonini

Labidus praedator (F. Smith, 1858)

0.01

Subfamília Ectatomminae

Tribo Ectatommini

Gnamptogenys striatula (Mayr, 1884)

0.11

0.16

Gnamptogenys sp. 1

0.01

Gnamptogenys sp. 2

0.01

Subfamily Formicinae

Tribe Camponotini

Camponotus (Myrmaphaenus) blandus (F. Smith, 1858)

Camponotus (Myrmepomis) sericeiventris (G.-M., 1838)

0.01

Camponotus (Myrmobrachys) crassus (Mayr, 1862)

Camponotus (Myrmothrix) cingulatus (Mayr, 1862)

Camponotus (Myrmothrix) rufipes (Fabricius, 1775)

Camponotus (Pseudocolobopsis) alboannulatus (Mayr, 1887)

Camponotus (Tanaemyrmex) lespesii (Forel, 1886)

\begin{tabular}{|c|c|c|c|c|}
\hline & 0.01 & 0.04 & & 0.02 \\
\hline & 0.01 & & & \\
\hline 0.01 & 0.03 & 0.17 & 0.04 & 0.04 \\
\hline 0.01 & 0.01 & & & \\
\hline 0.01 & & & & \\
\hline & 0.01 & 0.04 & & 0.02 \\
\hline & 0.01 & & & \\
\hline & 0.01 & 0.04 & & 0.02 \\
\hline 0.01 & & & & \\
\hline & 0.01 & & & \\
\hline
\end{tabular}

Camponotus sp. 1

Camponotus sp. 2

Camponotus sp. 3

0.01

Tribe Plagiolepidini

Brachymyrmex (Brachymyrmex) aphidicola (Forel, 1909)

0.03

Brachymyrmex (B.) coactus (Mayr, 1887)

Brachymyrmex sp.

0.01

Nylanderia fulva (Mayr, 1862)

0.01

Nylanderia sp.

0.04

0.15

Subfamily Heteroponerinae

Tribe Heteroponerini

Heteroponera inermis (Emery, 1894)

0.07

Heteroponera mayri (Kempf, 1962)

0.01

Subfamily Myrmicinae

Tribe Attini

Acromyrmex (Acromyrmex) disciger (Mayr, 1887)

Acromyrmex (A.) niger (F. Smith, 1858)

Acromyrmex (A.) subterraneus (Forel, 1893)

Apterostigma pilosum (Mayr, 1865)

\begin{tabular}{|l|l|}
\hline 0.01 & 0.01 \\
\hline 0.01 & 0.01 \\
\hline & 0.03 \\
\hline
\end{tabular}

0.04

0.02

0.02 
Table 1 - Continuation.

\begin{tabular}{|c|c|c|c|c|c|}
\hline Taxon & PPA & $\mathbf{F F}$ & CC & TC & PR \\
\hline Apterostigma wasmannii (Forel, 1892) & & 0.01 & & & \\
\hline Cyphomyrmex rimosus (Spinola, 1853) & 0.01 & & & & \\
\hline Mycocepurus goeldii (Forel, 1893) & 0.03 & & & & \\
\hline \multicolumn{6}{|l|}{ Tribe Blepharidattini } \\
\hline Wasmannia auropunctata (Roger, 1863) & & & & & 0.04 \\
\hline \multicolumn{6}{|l|}{ Tribe Cephalotini } \\
\hline Cephalotes pallidicephalus (F. Smith, 1876) & & 0.01 & & & \\
\hline Cephalotes pusillus (Klug, 1824) & 0.01 & 0.01 & & & 0.02 \\
\hline Cephalotes sp. 1 & & 0.01 & & & \\
\hline Cephalotes sp. 2 & 0.01 & 0.01 & & & \\
\hline Procryptocerus convergens (Mayr, 1887) & & 0.01 & & & 0.02 \\
\hline \multicolumn{6}{|l|}{ Tribe Crematogastrini } \\
\hline Crematogaster (Neocrema) corticicola (Mayr, 1887) & & 0.01 & & & \\
\hline Crematogaster sp. 1 & & 0.01 & & & \\
\hline Crematogaster sp. 2 & & 0.01 & & & \\
\hline \multicolumn{6}{|l|}{ Tribe Myrmicini } \\
\hline Pogonomyrmex angustus (Mayr, 1870) & 0.07 & 0.03 & & & \\
\hline Pogonomyrmex naegelii (Forel, 1878) & & & 0.04 & & 0.02 \\
\hline \multicolumn{6}{|l|}{ Tribe Pheidolini } \\
\hline Pheidole (Pheidole) brevicona (Mayr, 1887) & 0.03 & 0.03 & & 0.04 & \\
\hline Pheidole (Pheidole) lignicola (Mayr, 1887) & 0.05 & 0.04 & 0.13 & 0.22 & 0.14 \\
\hline Pheidole (Pheidole) risii (Forel, 1892) & 0.08 & 0.03 & & & 0.06 \\
\hline Pheidole sp. 1 & 0.03 & 0.03 & & & \\
\hline Pheidole sp. 2 & 0.05 & & 0.04 & & 0.12 \\
\hline Pheidole sp. 3 & 0.03 & & & & \\
\hline Pheidole sp. 4 & & & 0.13 & 0.15 & 0.04 \\
\hline Pheidole sp. 5 & & & 0.04 & & \\
\hline Pheidole sp. 6 & & 0.03 & & & \\
\hline Pheidole sp. 7 & & 0.01 & & & \\
\hline \multicolumn{6}{|l|}{ Tribe Solenopsidini } \\
\hline Solenopsis saevissima (F. Smith, 1855) & & & & & 0.02 \\
\hline Solenopsis sp. 1 & 0.03 & & 0.08 & 0.30 & \\
\hline Solenopsis sp. 2 & & & 0.04 & & 0.04 \\
\hline \multicolumn{6}{|l|}{ Subfamily Ponerinae } \\
\hline \multicolumn{6}{|l|}{ Tribe Ponerini } \\
\hline Hypoponera distinguenda (Emery, 1890) & 0.01 & & & & \\
\hline Hypoponera trigona (Mayr, 1887) & & & & 0.04 & \\
\hline Hypoponera sp. 1 & 0.01 & & & & \\
\hline Hypoponera sp. 2 & 0.01 & & & & \\
\hline Pachycondyla harpax (Fabricius, 1804) & & & & & 0.04 \\
\hline Pachycondyla striata (F. Smith, 1858) & 0.05 & 0.09 & & & 0.18 \\
\hline Pachycondyla villosa (Fabricius, 1804) & 0.01 & 0.04 & & & 0.02 \\
\hline \multicolumn{6}{|l|}{ Subfamily Pseudomyrmecinae } \\
\hline \multicolumn{6}{|l|}{ Tribe Pseudomyrmecini } \\
\hline Pseudomyrmex gracilis (Fabricius, 1804) & & 0.01 & & & 0.02 \\
\hline Pseudomyrmex termitarius (F. Smith, 1855) & 0.01 & 0.01 & & & \\
\hline
\end{tabular}

PPA: permanent preservation area; FF: forest fragment; CC: corn crop; TC: tobacco crop; PR: pine reforestation. 


\section{DISCUSSION}

The richness of ants found in the studied rural property represents $33.3 \%$ of the ant fauna currently known for the western region of Santa Catarina (ULYSSÉA et al., 2011; LUTINSKI et al., 2013a; LUTINSKI et al., 2017). This study represents the first survey of ants made in the municipality of Palma Sola, as well as it constitutes the first ant survey performed within a rural environment in the region. The ant assemblages found in the PPA and in the FF were similar in richness. However, they were $32.4 \%, 64.8 \%$ and $75.6 \%$ higher in richness than the PR, CC and TC assemblages, respectively. The nine ant species that showed a positive association with at least one of the sampled environments were also characterized as common and frequent in a previous regional study (LUTINSKI et al., 2014).

From the total of 69 species, 38 species occurred exclusively in the PPA and/or in the forest fragment. The richness estimate (Chao 2 ) indicates that the PPA and the FF have the richest ant assemblages amongst the sampled environments, followed by the PR, CC and TC environments, with decreasing expected richness esti- mates, respectively. The rarefaction curves showed no saturation, indicating that the sampling effort did not survey the ant assemblages fully, being thus possible to register additional ant species in all environments. Nevertheless, the lack of stabilization in the sampling curves is commonly observed for ant communities, a pattern that may be related to the aggregate distribution or rarity of some species (KLIMES et al., 2015).

The PPA and the FF represent the two environments with the highest number of plant species. The highest richness and the highest number of unique ant species in these environments seems to corroborate the predictions of Hölldobler and Wilson (1990), that point that the increase in the number of ant species occurs as the environments become more complex and are able to provide resources for the establishment of new populations. Lutinski et al. (2017) reported that forest formations host habitats and shelter for the insect fauna, having thus an important link between these two variables.

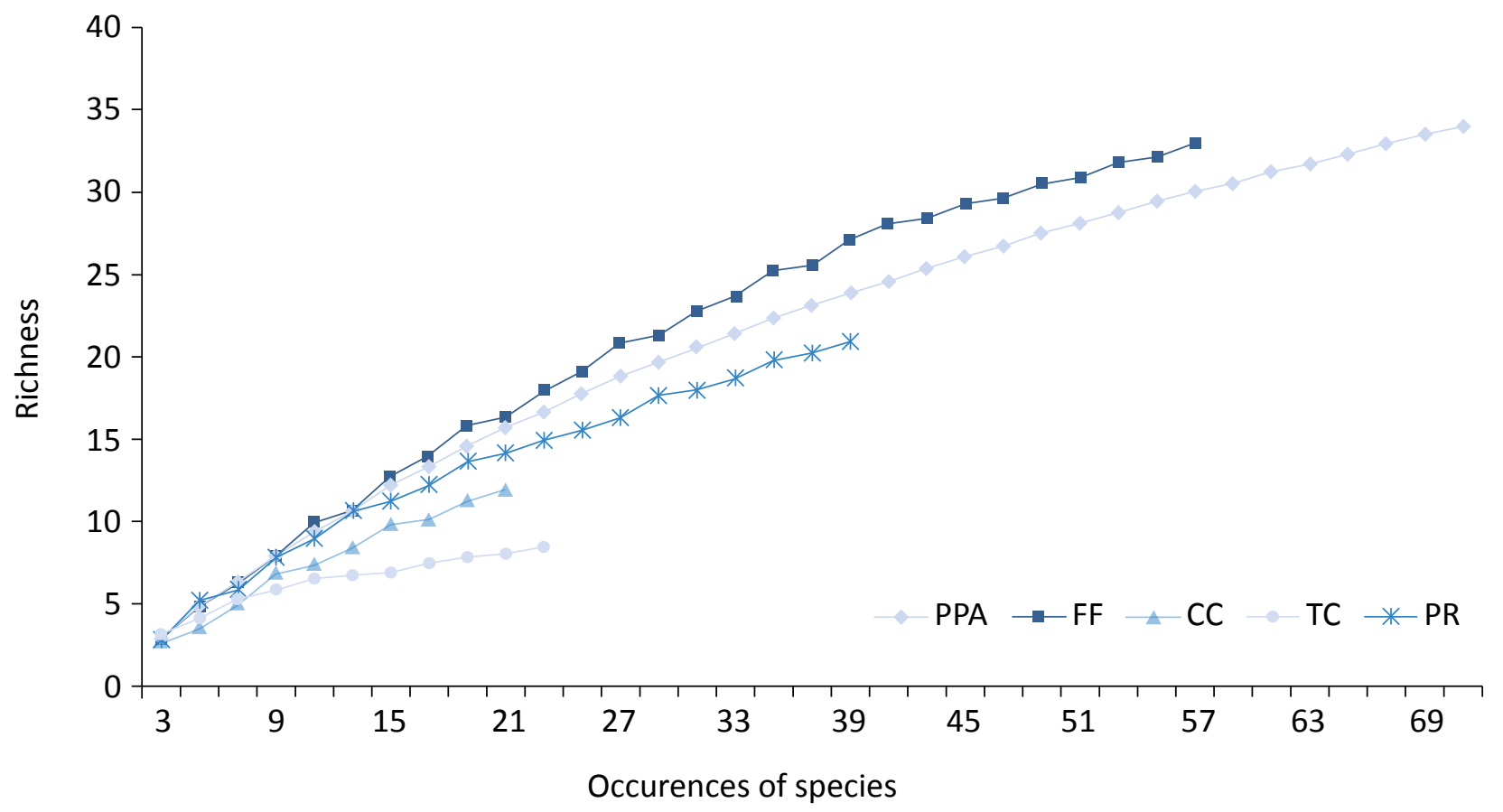

PPA: permanent preservation area; FF: forest fragment; CC: corn crop; TC: tobacco crop; PR: pine reforestation.

Figure 1 - Comparison by the rarefaction method, based on the number of occurrences and of the accumulated richness of ant assemblages from five environments in a rural property of Palma Sola municipality, western Santa Catarina, Brazil (December 2015). 
The ant assemblage from the PR, due to the environment age and undergrowth vegetation, presented a relative similarity to the assemblage sampled in the PPA and FF environments. There was a shared richness of nine species between the PR and the preserved environments (PPA and FF). A similar relationship was found by Lutinski et al. (2008). These authors also observed a higher richness of ants in the native vegetation compared to the pine reforestation, supporting the hypothesis that complex environments favor the increase in the ant richness.

The lowest ant richness was observed in both the CC and TC environments. This result is likely attributed to the characteristics of the conventional agricultural management used in these environments, which includes successive mechanical and chemical interventions, hence resulting in a decline in the ant fauna as compared to the other sampled environments.
Holdefer et al. (2017) attributed to these conventional agricultural practices the $50 \%$ decrease in the ant richness, a pattern that agrees with our results. Formicidae is a diverse taxon that may indicate the occurrence of other organisms in the environment (GUÉNARD et al., 2012; BISHOP et al., 2015), and thus the occurrence of ant species in agro ecosystems under conventional management may also indicate the tolerance ability that some ant species show (ILHA et al., 2009; CARVAL et al., 2016).

The richest genera were Camponotus and Pheidole, representing 17.0 and $14.5 \%$ of total species, respectively. This result is in accordance to the most recent and representative surveys of the ant fauna in the western region of Santa Catarina, performed by Lutinski et al. (2008; 2013a). Noteworthy is the record of Cephalotes pallidicephalus (F. Smith, 1876), a species with no recent regional records.

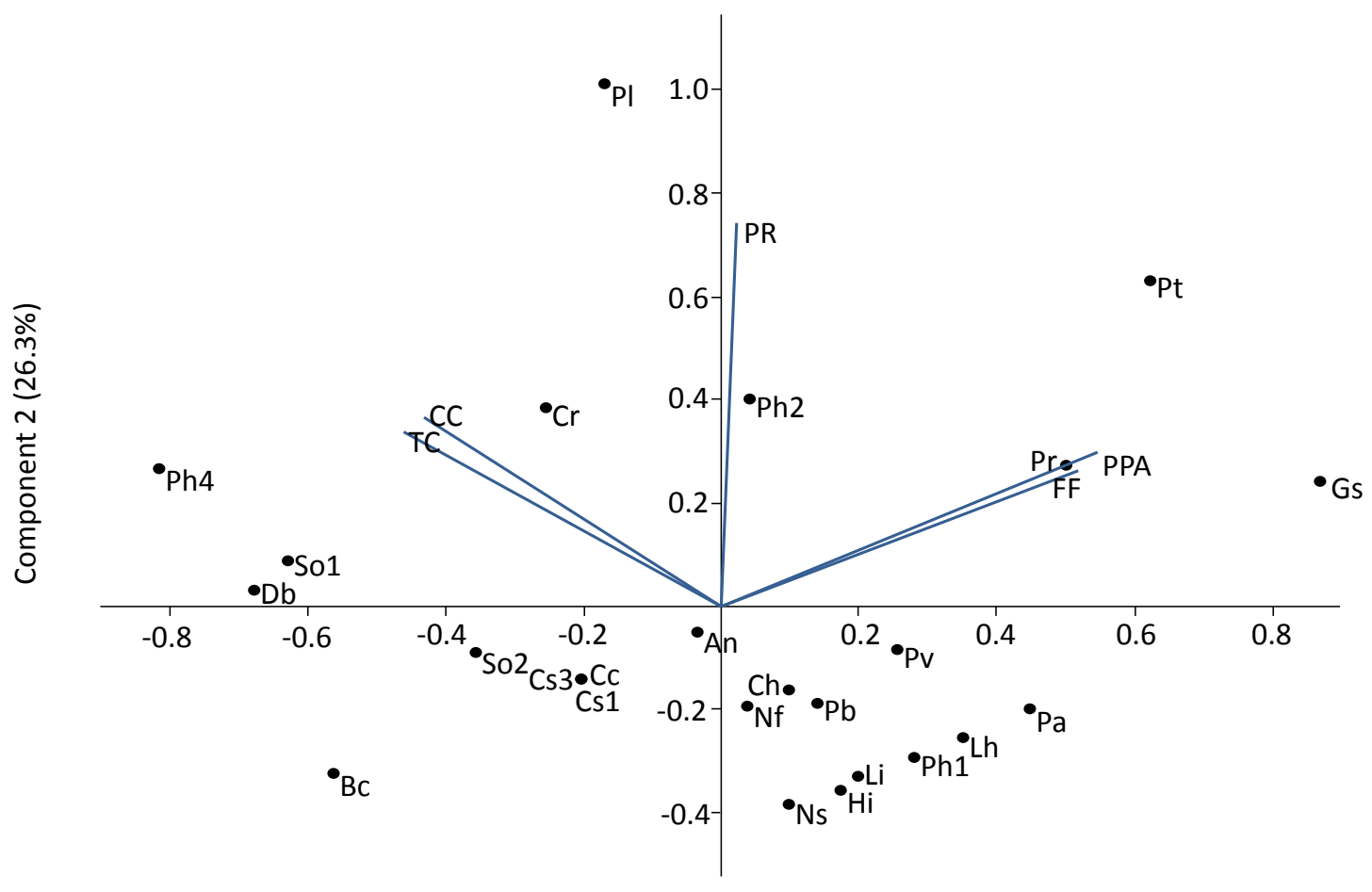

Component $1(39.0 \%)$

PPA: permanent preservation area; FF: forest fragment; CC: corn crop; TC: tobacco crop; PR: pine reforestation; An: Aspergillus niger; Bc: Brachymyrmex coactus; Cc: Camponotus crassus; Cr: Camponotus rufipes; Cs1: Camponotus sp. 1; Cs3: Camponotus sp. 3; Ch: Cephalotes pusillus; Db: Dorymyrmex brunneus; Gs: Gnamptogenys striatula; Hi: Heteroponera inermis; Lh: Linepithema humile; Li: Linepithema iniquum; Nf: Nylanderia fulva; Ns: Nylanderia sp.; Pt: Pachycondyla striata; Pv: Pachycondyla villosa; Pb: Pheidole brevicona; PI: Pheidole lignicola; Pr: Pheidole risii; Ph1: Pheidole sp. 1; Ph2: Pheidole sp. 2; Ph4: Pheidole sp. 4; Pa: Pogonomyrmex angustus; So1: Solenopsis sp. 1; So2: Solenopsis sp. 2.

Figure 2 - Association (principal component analysis) of ant species with five environments from a rural property located in the municipality of Palma Sola, western Santa Catarina, Brazil (December 2015). 
On the other hand, the recorded species belonging to the genera Dorymyrmex and Linepithema are characteristic of anthropogenic environments (ULYSSÉA et al., 2011; LUTINSKI et al., 2013a) and exert strong dominance over food sources. The occurrence of $D$. brunneus in the CC, TC and PR environments supports the findings of Lutinski et al. (2014), which also observed the association of this species with anthropogenic environments.

More than 300 species of Camponotus have been described for the Neotropics (FERNÁNDEZ, 2003), and among them an accentuated polymorphism occurs, as well as omnivorous diet. Chemical defense and mutualism are commonly observed in the relationships between these species and other organisms (SILVESTRE et al., 2003; BACCARO et al., 2015). Camponotus rufipes and C. sericeiventris are species widely distributed in the state of Santa Catarina (ULYSSÉA et al., 2011), common in anthropogenic environments (LUTINSKI et al., 2013a). The ability to colonize open and anthropogenic environments may explain the positive association of $C$. rufipes with the CC and TC environments.

The high diversity of Neotropical species of Solenopsis and Pheidole characterizes these genera as common in ant fauna studies, including dozens of species collected in a single locality (BACCARO et al., 2015; ECONOMO et al., 2017). The wide geographical distribution and their dispersion ability make some of these species locally abundant. Silvestre et al. (2003) discussed that these genera of ants exhibit a nesting behavior in the soil, form large colonies of small individuals, either monomorphic or dimorphic, have a generalist and aggressive behavior, and are strongly associated to disturbed environments. These life history aspects may explain the positive association of these genera with the CC, TC and PR environments.

The use of pesticides may be affecting the diversity of Formicidae in the western region of Santa Catarina, and potentially the diversity of other organisms. This claim is supported by the higher richness of the ant assemblages from the PPA and FF compared to the areas cultivated with corn and tobacco (CC and TC). In the state of Santa Catarina, agricultural activities cause loss and degradation of natural environments, including soil and water contamination by chemical pollutants such as fertilizers, insecticides, pesticides and herbicides. These factors directly affect the health of animals inhabiting rural and urban areas, including humans (MODEL et al., 2015). Clements (2000) points out that the effects of pesticides on wildlife range from physiological changes in a few organisms to the massive death of entire populations, therefore affecting the whole community structure. In general, the higher the concentration of pesticides and the longer the exposure time, the greater the chances of negative impacts reaching higher levels of biological organization, such as communities and ecosystems. If an environmental stress persists long enough to lead local populations to death - affecting their growth rates, reproduction, and preventing the re-colonization of the environment - , it is then able to affect the whole community structure (BARBIERI et al., 2013).

Agrochemicals can cause ecological imbalance by increasing the proliferation of pests and, consequently, the consumption of toxic compounds (LONDRES, 2011). The large-scale introduction of pesticides into the environment is considered one of the major factors leading to environmental contamination, especially in developing countries (COLLOTTA et al., 2013). The acephate, although currently banned in several countries in the European Union and in the United States, continues to be largely used in Brazil (ANVISA, 2010). Likewise, the broad-spectrum herbicide glyphosate represents around $40 \%$ of the total pesticide use in Brazil. The use of this compound underlies the biological resistance phenomenon in insects, hence requiring the use of a greater amount of the product in crops or a combination with other pesticides.

This study adds information on the richness and abundance of ants in the environmental mosaics that compose small farms western Santa Catarina. It presents a checklist of ant species from different types of environments - including those species able to survive in agro-ecosystems in which a conventional agricultural management is used - , and also provides information about the ant diversity inhabiting such environments. The study also indicates the occurrence of ant species associated with these different farm environments and, more broadly, suggests that there are complex factors acting in the ant assemblages from agricultural ecosystems.

The results show the importance of the conservation of PPA and environmental protection areas (FF) to the biodiversity conservation and as reservoirs for the adjacent environments recolonization. They also show a significant impact of conventional corn and tobacco cultivation on insect communities when compared to other activities on small farms. 


\section{REFERENCES}

AGÊNCIA NACIONAL DE VIGILÂNCIA SANITÁRIA (ANVISA). Programa de Análise de Resíduos de Agrotóxicos em Alimentos (PARA). 2010. Available from: <http://portal.anvisa.gov.br/programa-de-analise-de-registro-de-agrotoxicospara>. Accessed on: Feb. 4, 2016.

AGOSTI, D.; MAJER, J. D.; ALONSO, L. T.; SCHULTZ, T. Ants: standard methods for measuring and monitoring biodiversity. Washington, D.C.: Smithsonian Institution Press, 2000. 304 p.

BACCARO, B. B.; FEITOSA, R. M.; FERNÁNDEZ, F.; FERNANDES, I. O.; IZZO, T. J.; SOUZA, J. L. P.; SOLAR, R. Guia para os gêneros de formigas do Brasil. Manaus: INPA, 2015. 388p.

BARBIERI, R. F.; LESTER, P. J.; MILLER, A. S.; RYAN, K. G. A neurotoxic pesticide changes the outcome of aggressive interactions between native and invasive ants. Proceeding of Royal Society B, v. 280, n. 20132157, p. 1-7, 2013.

BHARTI, H.; BHARTI, M.; PFEIFFER, M. Ants as bioindicators of ecosystem health in Shivalik Mountains of Himalayas: assessment of species diversity and invasive species. Asian Myrmecology, v. 8, p. 1-15, 2016.

BISHOP, T. R.; ROBERTSON, M.; VAN RENSBURG, B.; PARR, C. L. Contrasting species and functional beta diversity in montane ant assemblages. Journal of Biogeography, v. 42, p. 1776-1786, 2015.

CARVAL, D.; COTTÉ, V.; RESMOND, R.; PERRIN, B.; TIXIER, P. Dominance in a ground-dwelling ant community of banana agroecosystem. Ecology and Evolution, v. 6, p. 8617-8631, 2016.

CHAGNON, M.; KREUTZWEISER, D.; MITCHELL, E. A. D.; MORRISSEY, C. A.; NOOME, D. A.; VAN DER SLUIJS, J. P. Risks of large-scale use of systemic insecticides to ecosystem functioning and services. Environmental Science and Pollution Research, v. 22, p. 119-134, 2015.

CHEVALIER, L. X. T.; GOMES, D. S.; MAYHÉ-NUNES, A. J.; QUEIROZ, J. M. Potencial de formigas (Hymenoptera: Formicidae) como agentes anti-herbívoros em cultivo de café (Coffea canephora Pierre) e Feijão Guandu [Cajanus cajans (L.) Millsp]. EntomoBrasilis, v. 6, n. 2, p. 113-118, 2013.

CLEMENTS, W. H. Integrating effects of contaminants across levels of biological organization: an overview. Journal of Aquatic Ecosystem Stress and Recovery, v. 7, p. 113-116, 2000.

COLLOTTA, M.; BERTAZZI, P. A.; BOLLATI, V. Epigenetics and pesticides. Toxicology, v. 307, p. 35-41, 2013.

CREPALDI, R. A.; PORTILHO, I. I. R.; SILVESTRE, R.; MERCANTE, F. M. Formigas como bioindicadores da qualidade do solo em sistema integrado lavoura-pecuária. Ciência Rural, v. 44, n. 5, p. 781-787, 2014.

DECOCQ, G.; ANDRIEU, E.; BRUNET, J.; CHABRERIE, O.; FRENNE, P.; SMEDT, P.; DECONCHAT, M.; DIEKMANN, M.; EHRMANN, S.; GIFFARD, B.; MIFSUD, E. G.; HANSEN, K.; HERMY, M.; KOLB, A.; LENOIR, J.; LIIRA, J.; MOLDAN, F.; PROKOFIEVA, I.; ROSENQVIST, L.; VARELA, E.; VALDÉS, A.; VERHEYEN, K.; WULF, M. Ecosystem Services from Small Forest Patches in Agricultural Landscapes. Current Forestry Reports, v. 2, p. 30-44, 2016.

ECONOMO, E. P.; KLIMOV, P.; SARNAT, E. M.; GUÉNARD, B.; WEISER, M. D.; LECROQ, B.; KNOWLES, L. L. Global phylogenetic structure of the hyperdiverse ant genus Pheidole reveals the repeated evolution of macroecological patterns. Proceeding of Royal Society B, v. 282, n. 20141416, p. 1-10, 2017.

EDWARDS, D. P.; GILROY, J. J.; WOODCOCK, P.; EDWARDS, F. A.; LARSEN, T. H.; ANDREWS, D. J. R.; DERHÉ, M. A.; DOCHERTY, T. D. S.; HSU, W. W.; MITCHELL, S. L.; OTA, T.; WILLIAMS, L. J.; LAURANCE, W. F.; HAMER, K. C.; WILCOVE, D. S. Land-sharing versus land-sparing logging: reconciling timber extraction with biodiversity conservation. Global Change Biology, v. 20, p. 183-191, 2014. 
FERNÁNDEZ, F. Introducción a las hormigas de la región neotropical. Bogotá: Instituto de Investigación de Recursos Biológicos Alexander von Humboldt, 2003. 426 p.

GALINDO-LEAL, C.; CÂMARA, I. G. The Atlantic Forest of South America: biodiversity status, threats, and outlook. Washington, D.C.: Island Press, 2003. 488 p.

GOTELLI, N. J.; ENTSMINGER, G. L. EcoSim: null models software for ecology. Version 7.0. Acquired Intelligence Inc. \& Kesey-Bear, 2001. Available from: <http://homepages.together.net/ gentsmin/ecosim.htm>. Accessed on: 23 mar. 2016.

GUÉNARD, B.; WEISER, M. D.; \& DUNN, R. R. Global models of ant diversity suggest regions where new discoveries are most likely are under disproportionate deforestation threat. PNAS, v. 109, n. 19, p. 7368-7373, 2012.

HAMMER, O.; HARPER, D. A. T.; RYAN, P. D. Past: palaeonthological statistics software package for education and data analysis. Version. 1.37. 2001. Available from: <http://palaeo-electronica.org/2001_1/past/issue1_01.htm>. Accessed on: Mar. 23, 2016.

HOLDEFER, D. R.; LUTINSKI, J. A.; GARCIA, F. R. M. Does organic management of agroecosystems contribute to the maintenance of the richness of ants? Semina: Ciências Agrárias, v. 38, n. 6, p. 3455-3468, 2017.

HÖLLDOBLER, B.; WILSON, E. O. The ants. Cambridge: Harvard University Press, 1990. 732 p.

ILHA, C.; LUTINSKI, J. A.; PEREIRA, D. V. M.; GARCIA, F. R. M. Riqueza de formigas (Hymenoptera: Formicidae) da Bacia da Sanga Caramuru, município de Chapecó-SC. Biotemas, v. 22, n. 4, p. 95-105, 2009.

INSTITUTO BRASILEIRO DE GEOGRAFIA E ESTATÍSTICA (IBGE). Cidades. 2015. Available from: <http://www.ibge.gov.br/ cidadesat/default.php>. Accessed on: Mar. 17, 2015.

KLIMES, P.; FIBICH, P.; IDIGEL, C.; RIMANDAI, M. Disentangling the Diversity of Arboreal Ant Communities in Tropical Forest Trees. PLoS One, v. 10, n. 2, p. 1-24, 2015.

LAWES, M. J.; MOORE, A. M.; ANDERSEN, A. N.; PREECE, N. D.; FRANKLIN, D. C. Ants as ecological indicators of rainforest restoration: community convergence and the development of an Ant Forest Indicator Index in the Australian wet tropics. Ecology and Evolution, v. 7, p. 8442-8455, 2017.

LONDRES, F. Agrotóxicos no Brasil: um guia para ação em defesa da vida. Rio de Janeiro: Cidade, 2011. 190 p.

LUTINSKI, J. A.; BAUCKE, L.; FILTRO, M.; BUSATO, M. A.; KNAKIEWICZ, A. C.; GARCIA, F. R. M. Ant assemblage (Hymenoptera: Formicidae) in three wind farms in the State of Paraná, Brazil. Brazilian Journal of Biology, v. 77, n. 1, p. 176-184, 2017.

LUTINSKI, J. A.; GARCIA, F. R. M.; LUTINSKI, C. J.; IOP, S. Diversidade de formigas na Floresta Nacional de Chapecó, Santa Catarina, Brasil. Ciência Rural, v. 38, n. 7, p. 1810-1816, 2008.

LUTINSKI, J. A.; LOPES, B.; MORAIS, A. B. B. Diversidade de formigas urbanas (Hymenoptera: Formicidae) de dez cidades do sul do Brasil. Biota Neotropica, v. 13, n. 3, p. 332-342, 2013 a.

LUTINSKI, J. A.; LUTINSKI, C .J.; IOP, S.; GARCIA, F. R. M. Evaluation of an ant sampling protocol (Hymenoptera: Formicidae) in three modified environments located inside an austral Atlantic Forest area of Brazil. Ecología Austral, v. 23, n. 1, p. 37-43, 2013b.

LUTINSKI, J. A.; LUTINSKI, C. J.; LOPES, B. C.; MORAIS, A. B. B. Estrutura da comunidade de formigas (Hymenoptera: Formicidae) em quatro ambientes com diferentes níveis de perturbação antrópica. Ecología Austral, v. 24, n. 2, p. 229-237, 2014. 
MODEL, D.; ESSWEIN, D.; GALLINA, L. S.; TEO, C. R. P. A.; NOTHAFT, S. C. S.; BUSATO, M. A. Ambiente e alimentação saudável: percepções e práticas de agricultores familiares. Campo-Território: Revista de Geografia Agrária, v. 10, n. 21, p. 142-158, 2015.

NICKELE, M. A.; REIS FILHO, W.; PIE, M. R.; PENTEADO, S. R. C. Daily Foraging Activity of Acromyrmex (Hymenoptera: Formicidae) Leaf-cutting Ants. Sociobiology, v. 63, n. 1, p. 645-650, 2016.

PÉREZ-SÁNCHEZ, A. J.; LATTKE, J. E.; VILORIA, A. L. Patterns of Ant (Hymenoptera: Formicidae) Richness and Relative Abundance along an Aridity Gradient in Western Venezuela. Neotropical Entomology, v. 42, p. 128-136, 2013.

RAMOS, A. M.; SANTOS, L. A. R.; FORTES, L. T. G. (Orgs.). Normais climatológicas do Brasil 1961-1990: edição revisada e ampliada. Brasília: INMET, 2009. 465 p.

ROCHA, W. O.; DORVAL, A; PERES FILHO, O.; VAEZ, C. A.; RIBEIRO, E. S. Formigas (Hymenoptera: Formicidae) Bioindicadoras de Degradação Ambiental em Poxoréu, Mato Grosso, Brasil. Floresta e Ambiente, v.22, n. 1, p. 88-98, 2015.

SILVESTRE, R.; BRANDÃO, C. R. F.; SILVA, R. R. Grupos funcionales de hormigas: el caso de los gremios del cerrado. In: FERNÁNDEZ, F. (Ed.). Introducción a las hormigas de la región neotropical. Bogotá, Colombia: Instituto de Investigación de Recursos Biológicos Alexander von Humboldt, 2003. p. 133-148.

TANENTZAP, A.; LAMB, A.; WALKER, S.; FARMER, A. Resolving Conflicts between Agriculture and the Natural Environment. PLoS Biology, v. 13, n. 9, p. 1-13, 2015.

ULYSSÉA, M. A.; CERETO, C. E.; ROSUMEK, F. B.; SILVA, R. R.; LOPES, B. C. Updated list of ant species (Hymenoptera, Formicidae) recorded in Santa Catarina State, southern Brazil, with a discussion of research advances and priorities. Revista Brasileira de Entomologia, v. 55, n. 4, p. 603-611, 2011.

WIELGOSS, A.; TSCHARNTKE, T.; RUMEDE, A.; FIALA, B.; SEIDEL, H.; SHAHABUDDIN, S.; CLOUGH, Y. Interaction complexity matters: disentangling services and disservices of ant communities driving yield in tropical agroecosystems. Proceeding of Royal Society B, v. 281, n. 1775, p. 1-10, 2013.

WILD, A. L. Taxonomic revision of the ant genus Linepithema (Hymenoptera: Formicidae). California: University of California Publications in Entomology, 2007. v. 126. 159 p. 